\title{
The aftereffect of winter wheat on pea yield, nitrogen surplus and nitrogen use efficiency in different cropping systems
}

\author{
Ivo Voor, Viacheslav Eremeev, Maarika Alaru and Evelin Loit \\ Chair of Crop Science and Plant Biology, Institute of Agricultural and Environmental Sciences, \\ Estonian University of Life Sciences, Kreutzwaldi 1, 51006 Tartu, Estonia \\ e-mail: ivo.voor@emu.ee
}

\begin{abstract}
The present study is part of a framework for researching the use of the field pea in cropping systems in order to improve its economic and environmental output. The specific aim was to investigate the effect of differently fertilised preceding winter wheat on subsequent field pea output in the same crop rotation. The field experiment was conducted in Tartu county, Estonia, in 2012-2017. Seven different cropping systems were investigated: four conventional with different treatments of mineral nitrogen fertilisers and three organic including catch crops and cattle manure treatment. The DM yield of field pea in winter wheat mineral $\mathrm{N}$ treatments $50-150 \mathrm{~kg} \mathrm{~N} \mathrm{ha}^{-1}$ was $2699-$ $2852 \mathrm{~kg} \mathrm{ha}^{-1}$, which was $33 \%$ higher than in the organic systems. There were no significant differences $(p<0.05)$ in nitrogen use efficiency (NUE) and N surplus between $50-150 \mathrm{~kg} \mathrm{~N} \mathrm{ha}^{-1}$. The first $20 \mathrm{~kg} \mathrm{ha}^{-1}$ mineral N with P25 and K95 gave a significantly higher pea yield compared to the treatment without mineral $\mathrm{N}$. The catch crops reduced agronomic NUE and increased $\mathrm{N}$ surplus in the organic cropping systems.
\end{abstract}

Key words: grain legumes, fertilisers, crop rotation, NUE, catch crops

\section{Introduction}

The field pea (Pisum sativum L.) is a protein crop grown for humans and animal consumption. As a leguminous plant, the pea fixes $\mathrm{N}_{2}$ from the atmosphere and enriches the soil for the next crop. While harvested pea grain seed is important as a foodstuff, the $\mathrm{N}$ accumulation of shoots and roots is valuable for $\mathrm{N}$ recovery in the soil. These pea residues contain a considerable amount of $\mathrm{N}$, which will be available for the subsequent crop. Field peas can fix atmospheric $\mathrm{N}_{2}$ up to $200 \mathrm{~kg} \mathrm{ha}^{-1}$ and approximately half of the fixed $\mathrm{N}$ remains in the soil and reduces the $\mathrm{N}$-fertiliser demand of subsequent crops (French 2016). $\mathrm{N}$-fertiliser use has been shown to decrease by $24 \%$ in arable legume-supported cropping systems, compared to systems without legumes (Reckling et al. 2016). On the other hand, legume residues with a low $\mathrm{C} / \mathrm{N}$ ratio can contribute to the loss of $\mathrm{N}$ due to rapid mineralization. In the pedoclimatic conditions of Estonia, crops utilize $40-50 \%$ of the $\mathrm{N}$ contained in mineral fertilizers in the first year and 50-60\% in the whole crop rotation (Astover et al. 2006). Therefore, improving nitrogen use efficiency (NUE) is essential for reducing damage through $\mathrm{NO}_{3}$ leaching, ecosystem saturation, and water pollution. NUE depends on $\mathrm{N}$ availability in the soil and how intensively plants use $\mathrm{N}$ throughout their life cycle. Increasing NUE and limiting $\mathrm{N}$-fertiliser use are both important and challenging for the preservation of the environment and improvement of sustainable and productive agriculture (Masclaux-Daubresse et al. 2010).

Field peas need little or no N-fertiliser - only a small amount at the beginning of growth is beneficial. So far, little attention has been paid to the effects of the preceding crop (pre-crop) on pea fertilisation. Higher pre-crop fertiliser application rates can obviously increase the amount of pre-crop residual $\mathrm{N}$. When the additional $\mathrm{N}$ is released by mineralisation during pea growth, it may affect the yield and nitrogen balance of the pea. A legume similar to the pea, the faba bean, provided $10 \%$ of extra yield after barley and $7 \%$ after oats compared to spring wheat (Lizarazo et al. 2015). Watson et al. (2017) concluded that the yield rise of the following legume crop can vary from 0 to $75 \%$ depending on legume fertilisation. The present study hypothesizes that differently fertilised winter wheat affects the yield and $\mathrm{N}$ balance of the subsequent pea. The study aimed to: (1) compare and analyse the aftereffect of winter wheat on the dry matter yield (DMY) of field peas in different cropping systems and (2) calculate $\mathrm{N}$ balance to assess $\mathrm{N}$ surplus and NUE of the field pea crop. By improving the understanding of pea yield variability and $\mathrm{N}$ usage, we can make suggestions for fertilising calculations and avoid $\mathrm{N}$ losses or $\mathrm{N}$ insufficiency. 


\section{AGRICULTURAL AND FOOD SCIENCE}

\section{Materials and methods \\ Field experiment}

The field experiment was conducted at the experimental station of the Estonian University of Life Sciences at

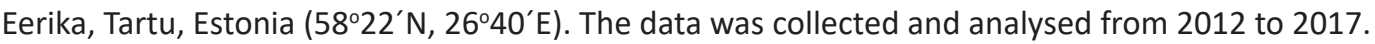

The plots were designed in a systematic block with four replications (Appendix 1). The experimental plots were non-randomized, because the same treatments on the same plots over the course of years allows to estimate the long-term effects of seven different cropping systems on soil properties. Fixed placement of cropping systems with different levels of fertilizer treatments allowed us to minimize the potential side effects. Each plot was $6 \mathrm{~m}$ wide and $10 \mathrm{~m}$ long $\left(60 \mathrm{~m}^{2}\right)$. The field was divided according to cropping systems: four different systems of conventional plots and three different systems of organic plots. The organic and conventional plots were separated with an 18- $\mathrm{m}$ wide section of grass to prevent the spread of synthetic plant protection products and mineral fertilisers. In this study, the field data were collected from plots of winter wheat and pea (Table 1). In conventional cropping systems (N1 N2, N3 and N4), both winter wheat and pea were treated with herbicide and fungicide. The five-year crop rotation was based on the following order of crops: barley undersown with red clover - red clover - winter wheat - field pea - potato. Every crop was grown in the field every year. The observed crops were the pea and preceding winter wheat (Triticum aestivum L.). In two organic cropping systems, different catch crops were used: after winter wheat, a mixture of winter oilseed rape (Brassica napus L.) and winter rye (Secale cereale L); after pea, winter oilseed rape (Brassica napus L).

\begin{tabular}{lll}
\multicolumn{3}{l}{ Table 1. Different fertiliser treatments of preceding crop and field pea in 7 different cropping systems } \\
\hline N1 & Pre-crop (winter wheat) & Field pea \\
N2 & no fertilisers & no fertilisers \\
N3 & N50P25K95* & N20P25K95 \\
N4 & N100P25K95 & N20P25K95 \\
Org1 & N150P25K95 & N20P25K95 \\
Org2 & no fertilisers & no fertilisers \\
Org3 & catch crops** & catch crops \\
$*$ nutrients added with mineral fertilisers in N2, N3 and N4; ** contains different amount of nutrients
\end{tabular}

${ }^{*}$ nutrients added with mineral fertilisers in N2, N3 and N4; ${ }^{* *}$ contains different amount of nutrients every year in Org2 and Org3

Mineral fertiliser was applied using a Fiona-brand manual seed drill and organic fertiliser was added manually. Wheat and pea seeds were sown by the Kverneland-brand roto seed drill and grain was harvested using a Sampo 2010 plot harvester. The pea crops were sown between the 22 April and the 12 May and the average growth period was 97 days.

The soil type in the experimental area was sandy loam Stagnic Albic Luvisol according to the FAO World Reference Base for soil resources 2014 (FAO 2015). The soil texture was sandy loam (56.5\% sand, 34\% silt and 9.5\% clay) for the epipedon with a humus layer of 20-30 cm (Reintam and Köster 2006). The nutrient content in the soil was: 14.8 $\mathrm{g} \mathrm{C} \mathrm{kg}^{-1}, 1.2 \mathrm{~g} \mathrm{~N} \mathrm{~kg}^{-1}, 109 \mathrm{mg} \mathrm{P} \mathrm{kg}^{-1}, 130 \mathrm{mg} \mathrm{K} \mathrm{kg}^{-1}, 143 \mathrm{mg} \mathrm{Mg} \mathrm{kg}^{-1}$ and $\mathrm{pH}_{\mathrm{KCL}} 5.8$ as an average of years 2012-2017.

\section{Sampling and chemical analysis}

Soil samples were taken from the 0-20 cm layer by a tubular soil sampler each April before ploughing in catch crops, fertilising and sowing. To remove bigger particles, a 2-mm mesh was used. At harvest, samples of pea grains, shoots and roots were taken annually from the test plot measuring $0.3 \mathrm{~m}^{2}$. To measure the dry matter of the biomass samples were dried for $48 \mathrm{~h}$ at $105^{\circ} \mathrm{C}$. $\mathrm{N}$ and $\mathrm{C}$ content in the biomass were determined by the Dumas method using the vario MAX CNS element analyser. In each plot, the grain yield was measured and the dry matter yield was calculated. 


\section{AGRICULTURAL AND FOOD SCIENCE}

\section{Weather conditions}

Temperatures and precipitation were measured by a meteorological station, which was located approximately $2 \mathrm{~km}$ from the experimental field. The data was obtained from the year 1969 until 2017, including the five-year period of the experiment. In this study, growing degree days (GDD) were calculated, which should correlate more accurately with plant growth and soil microorganism activity than mean circadian temperatures. GDD were calculated as the mean daily temperature above a $5^{\circ} \mathrm{C}$ base temperature accumulated on a daily basis over a year.

When comparing the experimental years and the 2012-2016 average, the GDD for plant growth and soil microorganisms activity was lower in 2015 and precipitation was lower in 2013 (Table 2).

Table 2. Temperature and precipitation during experiment years and long-term average

\begin{tabular}{lccccccc}
\hline & 2012 & 2013 & 2014 & 2015 & 2016 & 2012-2016 average & 1969-2011 average \\
\hline Growing degree days $\left({ }^{\circ} \mathrm{C}\right)^{*}$ & 1530 & 1769 & 1629 & 1449 & 1796 & 1635 & 1512 \\
Precipitation $(\mathrm{mm})$ & 634 & 494 & 542 & 495 & 539 & 541 & 586 \\
\hline
\end{tabular}

*sum of mean daily temperatures above $5^{\circ} \mathrm{C}$

\section{Methods of calculations}

The bulk density (BD) of soil was not measured but was calculated ( $\mathrm{BD}_{\text {calc }}$ ) according to Post and Kwon (2000) using the equation (1).

$\mathrm{BD}_{\text {calc }}=\frac{100}{\{(S O M / 10 / 0.244)+[(100-(\mathrm{SOM} / 10)) / 1.64]\}}$

where SOM is the soil organic matter content $\left(\mathrm{mg} \mathrm{g}^{-1}\right), 0.244$ is the bulk density of SOM, and 1.64 is the bulk density of the soil mineral matter (Kauer et al. 2015). Considering that SOM contains $58 \%$ of soil organic carbon (SOC) (Mann 1986) and SOC $=\mathrm{C} \%$, the conclusive equation (2) can be constructed:

$\mathrm{BD}_{\text {calc }}=\frac{100}{\{(\mathrm{C} \% / 0.58 / 0.244)+[(100-\mathrm{C} \% / 0.58) / 1.64]\}}$

The bulk density of the soil layer was determined by converting soil total $\mathrm{N} \%\left(10 \mathrm{~g} \mathrm{~N} \mathrm{~kg}^{-1}\right)$ to content $\mathrm{N}_{\text {soil }}\left(\mathrm{kg} \mathrm{N} \mathrm{Na}^{-1}\right)$ equation (3), which is better to compare when all other $\mathrm{N}$ contents are given in $\mathrm{kg}$ per hectare:

Nsoil $=$ BD $\times \mathrm{V}$

where $\mathrm{V}$ is the volume of soil.

$\mathrm{N}$ exists within the soil both in inorganic, such as ammonium $\mathrm{NH}_{4}^{+}$and nitrate $\mathrm{NO}_{3}{ }_{3}^{-}$, and organic forms. Bingham and Cotrufo (2016) conclude that in some soils, organic compounds can comprise up to $95 \%$ of soil N. According to Deng et al. (2000), organic forms of $\mathrm{N}$ account for $97-99 \%$ of total $\mathrm{N}$ whereas mineral $\mathrm{N}$ forms, which are available for plants, account for $1-3 \%$. In this experiment soil mineral $\mathrm{N}$ is assumed to be $2 \%$. The calculation of $\mathrm{N}_{\text {soil }}$ changes in soil is based on measuring soil total $\mathrm{N}$ content before and after pea growing.

The proportion of roots in total biomass $(18 \%)$ and root $\mathrm{N}$ content $(1.6 \%)$ were calculated previously at the same experimental station (Lauringson et al. 2011).

We determined total symbiotically fixed $\mathrm{N}_{2}$ where the $\mathrm{N}_{2}$ of root, shoot and grain were separately calculated and summed. $\mathrm{N}_{2}$ ratio to total $\mathrm{N}$ is used, which was determined using the ${ }^{15} \mathrm{~N}$ isotope diluting method (Carranca et al. 1999, Kumar and Goh 2000, Hauggaard-Nielsen et al. 2010). Considering this, it was assumed that grains, shoots and roots contain $70 \%, 52 \%$ and $72 \%$ of $\mathrm{N}$ derived from the atmosphere ( $\mathrm{Ndfa}$ ), respectively. The amount of fixed $\mathrm{N}_{2}$ was calculated using equation (4), where $\mathrm{N}_{2}$ content was calculated separately in each of the three parts of the pea plant.

$\mathrm{N}_{2}$ fixed $\left(\mathrm{kg} \mathrm{ha}^{-1}\right)=\frac{\% \mathrm{Ndfa}}{100} \times$ legume part total $\mathrm{N}$ 
The $\mathrm{N}$ balance includes the difference in soil $\mathrm{N}$ ( $\mathrm{N}$ stock $0-20 \mathrm{~cm}$ layer) in spring before and after the growth of peas, $\mathrm{N}$ applied as mineral and organic fertilisers, catch crops, pea plant residues and pea grain.

NUE refers to the efficiency of the field pea in using accumulated and added $\mathrm{N}$ for producing grain yield. According to Oenema et al. (2015), it is possible to use $\mathrm{N}$ input and $\mathrm{N}$ output data for the calculation of equation (5):

NUE $=\frac{\mathrm{N} \text { output }}{\mathrm{N} \text { input }}$

According to Moll et al. (1982), agronomic NUE (aNUE) is expressed as the ratio of grain dry matter to all N supplied from all available $\mathrm{N}$ sources. Using this definition, the NUE $\left(\mathrm{kg} \mathrm{DMY} \mathrm{kg}^{-1} \mathrm{~N}^{-1}\right)$ is calculated as equation (6)

aNUE $=\frac{\text { grain dry matter }}{\left(\mathrm{N}_{\text {soil }}+\mathrm{N}_{\mathrm{dfa}}+\mathrm{N}_{\mathrm{cc}}+\mathrm{N}_{\mathrm{fert}}\right)}$

where $\mathrm{N}_{\text {soil }}$ is $\mathrm{N}$ mineral amount in the soil before sowing, $\mathrm{N}_{\mathrm{dfa}}$ is $\mathrm{N}$ from the atmosphere, $\mathrm{N}_{c c}$ is accumulated $\mathrm{N}$ in cover crops, and $\mathrm{N}_{\text {fert }}$ is mineral or organic fertiliser.

\section{Statistical analysis}

Factorial analyses of variance (ANOVA) and two-factor ANOVA were used to test the effect of cropping systems and year on crop DM yield and soil N content. Factor "cropping system" was treated as a fixed categorical variable and "year" as random categorical variable. Descriptive analysis and Fisher's least significant difference test for homogenous groups were used for testing significance differences between cropping systems and experimental year. The level of statistical significance was set at $p<0.05$ if not indicated otherwise.

The software Statistica 13 (Quest Software Inc, Aliso Viejo, CA, USA) was used.

\section{Results and discussion \\ Changes in soil $\mathrm{N}$}

Changes in soil $\mathrm{N}$ are part of the $\mathrm{N}$ balance calculation where soil $\mathrm{N}$ content prior to sowing peas is on the input side and $\mathrm{N}$ content in next spring prior to sowing the subsequent crop is on the output side. On comparing the 5 -year average of the cropping systems, the organic cropping systems (Org1, Org2 and Org3) had significantly $(p<0.05)$ higher $\mathrm{N}$ soil content than the conventional cropping systems (Table 3 ); however, there were no significant differences in soil $\mathrm{N}$ before and after peas in any cropping system. Nonetheless, some years showed differences before and after peas: N content in the soil decreased in 2013 to 2014 and 2015 to 2016, and increased in 2014 to 2015 in some cropping systems (Appendix 2). The increase may be related to lower temperatures in 2015 (Table 2) where mineralization was lower.

Table 3. $\mathrm{N}$ content $\mathrm{kg} \mathrm{ha}^{-1}$ in soil in spring before and after growing field pea as an average in 2012-2017

\begin{tabular}{|c|c|c|c|c|c|c|c|}
\hline & N1 & N2 & N3 & N4 & Org1 & Org2 & Org3 \\
\hline Average before & $2987^{\text {Aa }}$ & $3124^{\mathrm{Aa}}$ & $3209^{\text {Aa }}$ & $3307^{\mathrm{Aa}}$ & $3774^{\mathrm{Ba}}$ & $3919^{\mathrm{Ba}}$ & $3818^{\mathrm{Ba}}$ \\
\hline
\end{tabular}

$\mathrm{N} 1$ and Org1 = symbiotically fixed $\mathrm{N}_{2} ; \mathrm{N} 2=\mathrm{N}_{2}$ + low mineral-N level; N3 = N2 + medium mineral N level; N4 = $\mathrm{N}_{2}+$ high mineral N level; Org2 = N2 + $\mathrm{N}$ taken up by catch crops NCC; Org3 $=\mathrm{N}_{2}+\mathrm{N}_{\mathrm{cC}}+\mathrm{N}$ applied cattle manure. *Different capital letters within each row indicate significantdifference (Fisher LSD, $p<0.05$ ) between cropping systems. ${ }^{* *}$ Different small letters within each column indicate significant difference (Fisher LSD, $p<0.05)$ between before and after growing field pea.

One possible explanation for the difference in $\mathrm{N}$ content in soil in conventional and organic cropping systems could be different carbon content. The carbon content has been higher in organic treatments (Kauer et al. 2015) and it is positively correlated with $\mathrm{N}$ content. Carbon contributes to keep different nutrients in the soil, including N. Another explanation could be related to the legume-associated bacteria that should be more active in not mineral-fertilised treatments, such as N1, Org1, Org2 and Org3, which is turn can cause increased atmospheric $\mathrm{N}$ accumulation.

Wheat residues were incorporated into the soil in the autumn and soil $\mathrm{N}$ was determined the following spring prior to pea sowing. Residues with a higher $\mathrm{C} / \mathrm{N}$ ratio, such as wheat, can cause a temporary $\mathrm{N}$ deficiency due to 


\section{AGRICULTURAL AND FOOD SCIENCE}

I. Voor et al. (2020) 29: 494-504

immobilisation (USDA 2011). However, increased $\mathrm{N}$ immobilisation does not always correlate to a decrease in the soil inorganic nitrogen concentration and negative $\mathrm{N}$ changes after residue incorporation are not caused by the residue but by unknown organic nitrogen fractions (Mueller et al. 1998, Nishio and Oka 2003, Shindo and Nishio 2005, Chen et al. 2014). On the contrary, pea residues with a lower C/N ratio than 24 will increase soil mineral $\mathrm{N}$ concentration and probably N surplus (Trinsoutrot et al. 2000). In the present experiment, both wheat residue $\mathrm{N}$ immobilisation and pea residue rapid mineralisation likely occurred. It is unclear which process dominated and led to changes in soil $\mathrm{N}$.

\section{DMY and $\mathrm{N}$ accumulation in pea}

Pea grain DMY was significantly $(p<0.05)$ higher in the conventional cropping systems where mineral fertiliser was added (Table 4). The mean value of N2, N3 and N4 was $2779 \mathrm{~kg} \mathrm{ha}^{-1}$ and it was $33 \%$ higher than in the organic systems. Differences in pea grain DMY between conventional and organic cropping systems were similar to some other studies (Gadermaier et al. 2011, Seufert et al. 2012), where it was greater than 34\%, but these differences were highly contextual. In conventional cropping systems, the DMY of N3 and N4 were statistically the same as in $\mathrm{N} 2$, despite the higher $\mathrm{N}$ mineral fertiliser treatment of the pre-crop (Table 4). This phenomenon can be explained by immobilisation of additional $\mathrm{N}$ caused by residues of the preceding winter wheat.

On comparing DMY of the three organic cropping systems, there was no significant $(p>0.05)$ difference between them, despite the addition of $\mathrm{N}$ with catch crops and manure (Table 4). Inversely, Madsen et al. (2016) and Talgre et al. (2011) showed that winter cover crops increase pea yields.

Table 4. Dry matter yield (DMY), nitrogen (N) accumulation by field pea and proportions of $\mathrm{N}$ accumulated in pea parts in different cropping systems (average of 2012-2016)

\begin{tabular}{|c|c|c|c|c|c|c|c|c|}
\hline & & N1 & N2 & N3 & N4 & Org1 & Org2 & Org3 \\
\hline \multirow[t]{3}{*}{ Grain } & $\operatorname{DMY}\left(\mathrm{kg} \mathrm{ha}^{-1}\right)$ & $1887^{a *}$ & $2852^{b}$ & $2699^{b}$ & $2786^{b}$ & $1804^{\mathrm{a}}$ & $1921^{\mathrm{a}}$ & $1799^{a}$ \\
\hline & $\mathrm{N}\left(\mathrm{kg} \mathrm{ha}^{-1}\right)$ & $57^{a}$ & $84^{b}$ & $84^{b}$ & $88^{b}$ & $56^{a}$ & $59^{a}$ & $55^{a}$ \\
\hline & $\%$ & 53 & 57 & 54 & 57 & 56 & 57 & 58 \\
\hline \multirow[t]{3}{*}{ Shoot } & DMY (kg ha-1) & $4266^{\mathrm{ab}}$ & $4675^{b}$ & $5318^{b}$ & $4620^{b}$ & $3486^{a}$ & $3375^{a}$ & $3328^{a}$ \\
\hline & $\mathrm{N}\left(\mathrm{kg} \mathrm{ha}^{-1}\right)$ & $33^{a b}$ & $41^{b}$ & $49^{b}$ & $45^{b}$ & $30^{\mathrm{a}}$ & $29^{a}$ & $26^{a}$ \\
\hline & $\%$ & 31 & 28 & 32 & 29 & 30 & 28 & 27 \\
\hline \multirow[t]{3}{*}{ Root } & DMY (kg ha-1) & $1108^{a}$ & $1355^{b}$ & $1443^{b}$ & $1333^{b}$ & $952^{a}$ & $953^{a}$ & $923^{a}$ \\
\hline & $\mathrm{N}\left(\mathrm{kg} \mathrm{ha}^{-1}\right)$ & $18^{\mathrm{a}}$ & $22^{b}$ & $23^{b}$ & $21^{\mathrm{b}}$ & $15^{\mathrm{b}}$ & $15^{\mathrm{b}}$ & $15^{\mathrm{b}}$ \\
\hline & $\%$ & 16 & 15 & 15 & 14 & 15 & 15 & 15 \\
\hline \multirow[t]{2}{*}{ Total biomass } & DMY (kg ha-1) & $7260^{a}$ & $8882^{b}$ & $9460^{b}$ & $8738^{b}$ & $6242^{\mathrm{a}}$ & $6246^{a}$ & $6049^{a}$ \\
\hline & $\mathrm{N}\left(\mathrm{kg} \mathrm{ha}^{-1}\right)$ & $108^{a}$ & $147^{b}$ & $155^{b}$ & $155^{b}$ & $101^{\mathrm{a}}$ & $103^{a}$ & $96^{a}$ \\
\hline
\end{tabular}

$\mathrm{N} 1$ and Org1 = symbiotically fixed $\mathrm{N}_{2} ; \mathrm{N} 2$ = $\mathrm{N}_{2}$ + low mineral-N level; N3 = N2 + medium mineral N level; N4 = N + high mineral N level; Org2 = N2 $+\mathrm{N}$ taken up by catch crops NCC;Org3 $=\mathrm{N}_{2}+\mathrm{N}_{\mathrm{cc}}+\mathrm{N}$ applied cattle manure. *Different letters within each row indicate significant differences (Fisher LSD, $p<0.05$ ) between cropping systems.

$\mathrm{N}$ accumulation in the pea plant shows how much $\mathrm{N}$ was removed from the field through yield and how much $\mathrm{N}$ was incorporated into the soil with the pea residues. The $\mathrm{N}$ amounts in harvestable grain seeds were correlated to grain DMY and the mean value of N2, N3 and N4 was 33\% higher than the mean value of the organic cropping systems.

Total $\mathrm{N}$ accumulation in pea biomass depends on the percentage of $\mathrm{N}$ content in the plant and the amount of DM. Total $\mathrm{N}$ in pea biomass was higher in mineral-fertilised cropping systems (145-155 kg ha $\left.{ }^{-1}\right)$. In comparison, the total $\mathrm{N}$ amount can be much higher if there is double $\mathrm{N}$ and C content in the soil, such as in Kumar and Goh (2000) in New Zealand, whose total N was $427 \mathrm{~kg} \mathrm{ha}^{-1}$ and total biomass yield was extremely high (15300 kg ha-1). In the present study, the total biomass DMY of the pea was $6049-9460 \mathrm{~kg} \mathrm{ha}^{-1}$.

The proportions of accumulated $\mathrm{N}$ in grain, shoots and roots were similar in all different cropping systems. 53-58\% of the total nitrogen content was accumulated in grain, $27-32 \%$ in shoots and $14-16 \%$ in roots. In comparison, with high fertilisation, Kumar and Goh (2000) gained $28 \%, 61 \%$ and $12 \%$, respectively. 


\section{AGRICULTURAL AND FOOD SCIENCE}

I. Voor et al. (2020) 29: 494-504

\section{$\mathrm{N}$ surplus and NUE}

$\mathrm{N}$ balance estimates the potential surplus of nitrogen on agricultural land. $\mathrm{N}$ balance represents the difference between $\mathrm{N}$ input and $\mathrm{N}$ output (Table 5). Soil $\mathrm{N}$ and $\mathrm{N}$ accumulation in pea plants is described in the previous sections. Thereafter, the symbiotically fixed $\mathrm{N}_{2}$, the $\mathrm{N}$ of the mineral fertiliser and the catch crops is taken into account.

First, symbiotically fixed $\mathrm{N}_{2}$ amounts were separately calculated in grain, shoots and roots, and after that, the results were summed. $\mathrm{N}_{2}$ amounts were significantly $(p<0.05)$ higher in N2, N3 and N4 (99-104 kg N ha $\left.{ }^{-1}\right)$, where mineral fertilisers were added, compared to non-mineral fertilised N1, Org1, Org2 and Org3 (65-72 kg N ha-1). Despite the different mineral $\mathrm{N}$ treatment of the preceding winter wheat crop in N2, N3 and N4, there was no significant $(p>0.05)$ difference in $\mathrm{N}_{2}$ amounts of the pea. In comparison, the mean $\mathrm{N}_{2}$ fixation of pea in Europe according to Watson (2017) was considerably higher (141 kg N ha-1).

The catch crops in Org2 and Org3 obtained 31-36 kg N ha-1 $(p>0.05)$ before field pea and 18-23 $\mathrm{kg} \mathrm{N} \mathrm{ha}^{-1}(p>0.05)$ after field pea, respectively. Differences in catch crop biomass before and after peas were most likely caused by the different number of catch crops species used: after winter wheat, a mixture of winter oilseed rape and winter rye, but after pea only winter oilseed rape.

Table 5. $\mathrm{N}$ surplus $\left(\mathrm{kg} \mathrm{ha}^{-1}\right)$, nitrogen use efficiency (NUE) and agronomic NUE ( $\mathrm{kg} \mathrm{DMY} \mathrm{kg}^{-1} \mathrm{~N}$ ) of field pea as an average 2012-2016

\begin{tabular}{|c|c|c|c|c|c|c|c|}
\hline & N1 & N2 & N3 & N4 & Org1 & Org2 & Org3 \\
\hline \multicolumn{8}{|l|}{$\mathrm{N}$ input } \\
\hline Mineral $\mathrm{N}$ in soil before & $60^{a *}$ & $62^{\mathrm{a}}$ & $64^{\mathrm{a}}$ & $66^{\mathrm{a}}$ & $75^{b}$ & $78^{b}$ & $76^{\mathrm{b}}$ \\
\hline Symbiotic $\mathrm{N}_{2}$ fixation & $74^{\mathrm{a}}$ & $101^{\mathrm{b}}$ & $105^{b}$ & $105^{b}$ & $69^{a}$ & $71^{\mathrm{a}}$ & $66^{\mathrm{a}}$ \\
\hline $\mathrm{N}$ mineral fertilisation & $0^{\mathrm{a}}$ & $20^{\mathrm{b}}$ & $20^{\mathrm{b}}$ & $20^{\mathrm{b}}$ & $0^{\mathrm{a}}$ & $0^{\mathrm{a}}$ & $0^{\mathrm{a}}$ \\
\hline Cover crops $\mathrm{N}$ before & $0^{\mathrm{a}}$ & $0^{\mathrm{a}}$ & $0^{\mathrm{a}}$ & $0^{\mathrm{a}}$ & $0^{\mathrm{a}}$ & $31^{b}$ & $36^{b}$ \\
\hline \multicolumn{8}{|l|}{$\mathrm{N}$ output } \\
\hline Mineral $\mathrm{N}$ in soil after & $57^{a}$ & $63^{\mathrm{a}}$ & $62^{\mathrm{a}}$ & $61^{\mathrm{a}}$ & $71^{\mathrm{b}}$ & $75^{\mathrm{b}}$ & $75^{\mathrm{b}}$ \\
\hline Grain N removal & $57^{a}$ & $84^{b}$ & $84^{b}$ & $88^{b}$ & $56^{a}$ & $59^{\mathrm{a}}$ & $55^{a}$ \\
\hline Cover crops $\mathrm{N}$ after & $0^{\mathrm{a}}$ & $0^{\mathrm{a}}$ & $0^{\mathrm{a}}$ & $0^{\mathrm{a}}$ & $0^{\mathrm{a}}$ & $18^{\mathrm{b}}$ & $23^{b}$ \\
\hline $\mathrm{N}$ surplus ( $\mathrm{N}$ input- $\mathrm{N}$ output) & $20^{\mathrm{ab}}$ & $36^{\text {cd }}$ & $43^{d}$ & $42^{d}$ & $17^{\mathrm{a}}$ & $28^{\mathrm{bc}}$ & $25^{a b c}$ \\
\hline NUE (N output / N input $\times 100$ ) & $84^{\mathrm{bc}}$ & $80^{\mathrm{ab}}$ & $77^{a}$ & $78^{\mathrm{a}}$ & $90^{c}$ & $85^{b c}$ & $86^{b c}$ \\
\hline Agronomic NUE (grain yield / N input) & $14^{\mathrm{bc}}$ & $16^{\mathrm{d}}$ & $14^{\text {cd }}$ & $15^{\mathrm{cd}}$ & $12^{\mathrm{b}}$ & $10^{\mathrm{a}}$ & $10^{\mathrm{a}}$ \\
\hline
\end{tabular}

A higher $(p<0.05) \mathrm{N}$ surplus occurred in N3 and N4 $\left(42-43 \mathrm{~kg} \mathrm{~N} \mathrm{ha}^{-1}\right)$ compared to N1, Org1, Org2 and Org3 (17$28 \mathrm{~kg} \mathrm{~N} \mathrm{ha}^{-1}$ ) and compared to two organic cropping systems, Org1 (17 kg N ha-1) and Org2 (28 kg N ha-1), which was likely caused by catch crops. $\mathrm{N}$ surplus is an important value, because it can cause $\mathrm{N}$ loss due to leaching and ammonification. Previous studies indicate reasons for and amounts of $\mathrm{N}$ surplus comparable to the present study. Pattinson and Pattinson (1985) found that estimated annual $\mathrm{NO}_{3}$ leaching losses in peas could be $90 \mathrm{~kg} \mathrm{ha}^{-1}$ and that it is dependent on preceding crop residues. A low $\mathrm{C} / \mathrm{N}$ ratio is generally associated with intensive mineralisation (Franzluebbers and Hill 2005). The results of Kumar and Goh (2000) and Talgre et al. (2017) confirm that a higher $\mathrm{C} / \mathrm{N}$ ratio of plant shoots is negatively correlated with $\mathrm{N}$ mineralisation. Beaudoin et al. (2005) concluded that leaching was greatly affected by pea residue decomposition without catch cropping. In the present study, $\mathrm{N}$ immobilisation most probably occurred after the incorporation of the residues of the preceding winter wheat crop and $\mathrm{NO}_{3}$ leached after the incorporation of pea residues. Both processes resulted in $\mathrm{N}$ surplus.

NUE shows how efficiently a crop uses $\mathrm{N}$, where $\mathrm{N}$ output is divided by $\mathrm{N}$ input, and multiplied by 100 . The highest $(p<0.05)$ NUE (90\%) was in Org1 compared to the mineral-fertilised cropping systems N2 (80\%), N3 (77\%) and N4 (78\%), which total N input was higher. The differences between mineral-fertilised and non-mineral fertilised cropping systems taken separately were insignificant. 


\section{AGRICULTURAL AND FOOD SCIENCE}

I. Voor et al. (2020) 29: 494-504

Agronomic NUE expresses how much grain was produced per one kilo N input. A significantly $(p<0.05)$ lower agronomic NUE could be observed in Org2 and Org3 (10-11 kg DMY kg-1 N) where catch crops and cattle manure were added. The low mineral fertilised cropping system N2 had significantly $(p<0.05)$ higher agronomic NUE $\left(16 \mathrm{~kg} \mathrm{DMY} \mathrm{kg}^{-1} \mathrm{~N}\right)$ than the non-mineral fertilised cropping systems $\mathrm{N} 1$, Org1, Org2 and Org3 (10-14 kg DMY kg-1 N).

There are several ways to carry on with the field experiment analysed in this paper to address the limitations and to further improve the knowledge. We chose to use simplified N balance as described by Kumar (2000), thus the atmospheric deposition of $\mathrm{N}$, rhizodeposition of $\mathrm{N}$, and $\mathrm{N}$ in seeds and weeds were not accounted for. The symbolic fixation of $\mathrm{N}_{2}$ had a considerable effect on $\mathrm{N}$ surplus and NUE. For the $\mathrm{N}_{2}$ calculation we used values from the literature, where grains, shoots and roots contain $70 \%, 52 \%$ and $72 \%$ of $\mathrm{N}$ derived from atmosphere, respectively. This percentage may vary in different growing environment, which can change both $\mathrm{N}$ surplus and NUE. Future studies could focus on measuring these values in our field experiment, which would provide more precise results.

The study was conducted in soil with a low nutrient content, including low $\mathrm{N}$ content, thus mineral fertiliser N20P25K95 N in treatments N2, N3 and N4 provided a significantly higher pea yield compared to N1 and all organic treatments. The aftereffect of different fertilisation of winter wheat on pea was less significant. It would be beneficial to address the same questions in different soil types.

\section{Conclusion}

The aftereffect of three different mineral $\mathrm{N}$ treatments of winter wheat had the same impact on the subsequent pea crop: N50, N100 and N150 gave 2699-2852 kg ha-1 grain DMY. In three organic cropping systems, the grain DMY was 33\% lower, 1799-1921 kg ha-1. Organic cropping systems where catch crops and added cattle manure was used, had no effect on DMY and NUE. There was no difference in NUE between cropping systems that were not mineral fertilised and were treated with pesticides, and the three organic cropping systems.

The $\mathrm{N}$ surplus of medium and higher mineral $\mathrm{N}$ treatments of the winter wheat pre-crop (N100 and N150) was 42-43 kg N ha-1 and was higher compared with all four treatments where mineral fertiliser was not applied. The catch crops increased $\mathrm{N}$ surpluses from $17 \mathrm{~kg} \mathrm{ha}^{-1}$ to $28 \mathrm{~kg} \mathrm{~N} \mathrm{ha}^{-1}$.

The NUE of mineral N treatments (N100 and N150) was 77-78\%, which was lower compared with a range 84-90\% for the four treatments where mineral fertiliser was not applied. Catch crops and cattle manure had no effect on NUE in the organic cropping systems.

Agronomic NUE of mineral $\mathrm{N}$ treatment $\mathrm{N} 50$ was $16 \mathrm{~kg} \mathrm{DMY} \mathrm{kg}^{-1} \mathrm{~N}$, which was higher than the range 10-14 DMY $\mathrm{kg}^{-1} \mathrm{~N}$ for the four treatments where mineral fertiliser was not applied ; however, there was no statistically significant difference $(p>0.05)$ between N50, N100 and N150. The catch crops and cattle manure reduced agronomic NUE from 12 to $10 \mathrm{~kg} \mathrm{ha}^{-1} \mathrm{~N}$ in the organic cropping systems.

\section{Acknowledgements}

This work was supported by basic funding project "From soil to yield: comparison of soil, plant growth and yield on different farming systems". Project number 8-2/T13001PKTM, Estonian University of Life Sciences. We are thankful to Dr. James Holmes for the linguistic advice.

\section{References}

Astover, A., Roostalu, H., Lauringson, E., Lemetti, I., Selge, A., Talgre, L., Vasiliev, N., Mõtte, M., Tõrra, T. \& Penu, P. 2006. Changes in agricultural land use and in plant nutrient balances of arable soils in Estonia. Archives of Agronomy and Soil Science 52: 223231.https://doi.org/10.1080/03650340600638883

Beaudoin, N., Saad, J.K., Van Laethem, C., Machet, J.M., Maucorps, J. \& Mary, B. 2005. Nitrate leaching in intensive agriculture in Northern France: Effect of farming practices, soils and crop rotations. Agriculture, Ecosystems \& Environment 111: 292-310. https://doi.org/10.1016/j.agee.2005.06.006

Bingham, A.H. \& Cotrufo, M.F. 2016. Organic nitrogen storage in mineral soil: Implications for policy and management. Science of The Total Environment 551-552: 116-126. https://doi.org/10.1016/j.scitotenv.2016.02.020.

Carranca, C., de Varennes, A. \& Rolston, D. 1999. Biological nitrogen fixation by fababean, pea and chickpea, under field conditions, estimated by the $15 \mathrm{~N}$ isotope dilution technique. European Journal of Agronomy 10: 49-56.

https://doi.org/10.1016/S1161-0301(98)00049-5 
Chen, B., Liu, E., Tian, Q., Yan, C. \& Zhang, Y. 2014. Soil nitrogen dynamics and crop residues. A review. Agronomy for Sustainable Development 34: 429-442. https://doi.org/10.1007/s13593-014-0207-8

Deng, S.P., Moore, J.M. \& Tabatabai, M.A. 2000. Characterization of active nitrogen pools in soils under different cropping systems. Biology and Fertility of Soils 32: 302-309. https://doi.org/10.1007/s003740000252

FAO 2015. World reference base for soil resources 2014: international soil classification system for naming soils and creating legends for soil maps, World soil resources reports 106. Cited 11 January 2019. http://www.fao.org/3/a-i3794e.pdf

Franzluebbers, A.J. \& Hill, N.S. 2005. Soil carbon, nitrogen and ergot alkaloids with short and long-term exposure to endophyte infected and endophyte free tall fescue. Soil Science Society of America Journal 69: 404-412. https://doi.org/10.2136/sssaj2005.0404

French, R.J. 2016. Field Pea: Agronomy. Reference module in food science. https://doi.org/10.1016/B978-0-08-100596-5.00196-7

Gadermaier, F., Berner, A., Fließbach, A., Friedel, J.K. \& Mäder, P. 2011. Impact of reduced tillage on soil organic carbon and nutrient budgets under organic farming. Renewable Agriculture and Food Systems 27: 68-80. https://doi.org/10.1017/S1742170510000554

Hauggaard-Nielsen, H., Holdensen, L., Wulfsohn, D. \& Jensen, E.S. 2010. Spatial variation of $\mathrm{N}_{2}$-fixation in field pea (Pisum sativum $\mathrm{L}$.) at the field scale determined by the $15 \mathrm{~N}$ natural abundance method. Plant Soil 327: 167-184. https://doi.org/10.1007/s11104-009-0043-9

Kauer, K., Tein, B., Sanchez de Cima, D., Talgre, L., Eremeev, V., Loit, E. \& Luik, A. 2015. Soil carbon dynamics estimation and dependence on farming system in a temperate climate. Soil and Tillage Research 154: 53-63. https://doi.org/10.1016/j.still.2015.06.010

Kumar, K.M. \& Goh, K. 2000. Crop residues and management practices: effects on soil quality, soil nitrogen dynamics, crop yield and nitrogen recovery. Advances in Agronomy 68: 197-319. https://doi.org/10.1016/S0065-2113(08)60846-9

Lauringson, E., Talgre, L., Roostalu, H. \& Makke, A. 2011. Possibilities for regulating humus condition and nutrient balance and phytoproductivity of green manure crops in conventional and organic farming. Estonian University of Life Science. Cited 04 November 2019. https://www.pikk.ee/upload/files/Teadusinfo/Lauringson_PMaruanne.pdf

Lizarazo, C.I., Stoddard, F.L. \& Yli-Halla, M. 2015. Pre-crop effects on the nutrient composition and utilization efficiency of faba bean (Vicia faba L.) and narrow-leafed lupin (Lupinus angustifolius L.). Nutrient Cycling in Agroecosystems 103: 311-327. https://doi.org/10.1007/s10705-015-9743-0

Madsen, H., Talgre, L., Eremeev, V., Alaru, M., Kauer, K. \& Luik, A. 2016. Do green manures as winter cover crops impact the weediness and crop yield in an organic crop rotation? Biological Agriculture \& Horticulture 32: 182-191.

https://doi.org/10.1080/01448765.2016.1138141

Mann, L.K. 1986. Changes in soil carbon storage after cultivation. Soil Science 142: 279-288.

https://doi.org/10.1097/00010694-198611000-00006

Masclaux-Daubresse, C., Daniel-Vedele, F., Dechorgnat, J., Chardon, F., Gaufichon, L. \& Suzuki, A. 2010. Nitrogen uptake, assimilation and remobilization in plants: challenges for sustainable and productive agriculture. Annals of Botany 105: 1141-1157. https://doi.org/10.1093/aob/mcq028

Moll, R.H., Kamprath, E.J. \& Jackson, W.A. 1982. Analysis and Interpretation of Factors Which Contribute to Efficiency of Nitrogen Utilization1. Agronomy Journal 74: 562-564. https://doi.org/10.2134/agronj1982.00021962007400030037x.

Mueller, T., Jensen, L.S., Nielsen, N.E. \& Magid, J. 1998. Turnover of carbon and nitrogen in a sandy loam soil following incorporation of chopped maize plants, barley straw and blue grass in the field. Soil Biology and Biochemistry 30: 561-571. https://doi.org/10.1016/S0038-0717(97)00178-8

Nishio, T. \& Oka, N. 2003. Effect of organic matter application on the fate of $15 \mathrm{~N}$-labeled ammonium fertilizer in an upland soil. Soil Science and Plant Nutrition 49: 397-403. https://doi.org/10.1080/00380768.2003.10410025

Oenema, O., Brentrup, F., Lammel, J., Bascou, P., Billen, G., Dobermann, A., Erisman, W., Garnett, T., Hammel, M., Haniotis, T., Hillier, J., Hoxha, A., Jensen, L., Oleszek, W., Pallière, C., Powlson, D., Quemada, M., Schulman, M., Sutton, M. \& Winiwarter, W. 2015. Nitrogen Use Efficiency (NUE) an indicator for the utilization of nitrogen in food systems. EU Nitrogen Expert Panel Secretariat: Wageningen University. Cited 12 Nov 2019. http://www.eunep.com/wp-content/uploads/2017/03/N-ExpertPanel-NUE-Session-1.pdf

Pattinson, J.A.A. \& Pattinson, J.M. 1985. Nitrate leaching losses under a legume-based crop rotation in Central Canterbury, New Zealand. New Zealand Journal of Agricultural Research 28: 101-107. https://doi.org/10.1080/00288233.1985.10427002

Post, W.M. \& Kwon, K.C. 2000. Soil carbon sequestration and land-use change: processes and potential. Global Change Biology 6: 317-327. https://doi.org/10.1046/j.1365-2486.2000.00308.x

Reckling, M., Bergkvist, G., Watson, C.A., Stoddard, F.L., Zander, P.M., Walker, R., Pristeri, A., Toncea, I. \& Bachinger, J. 2016. Tradeoffs between economic and environmental impacts of introducing legumes into cropping systems. Frontiers in Plant Science 7: 669. https://doi.org/10.3389/fpls.2016.00669

Reintam, E. \& Köster, T. 2006. The role of chemical indicators to correlate some Estonian soils with WRB and Soil Taxonomy criteria. Geoderma 136: 199-209. https://doi.org/10.1016/j.geoderma.2006.03.028

Sainju, U.M. 2017. Determination of nitrogen balance in agroecosystems. Methods X 4: 199-208.

https://doi.org/10.1016/j.mex.2017.06.001

Seufert, V., Ramankutty, N. \& Foley, J.A. 2012. Comparing the yields of organic and conventional agriculture. Nature 485: 229232. https://doi.org/10.1038/nature11069.

Shindo, H. \& Nishio, T. 2005. Immobilization and remineralization of $\mathrm{N}$ following addition of wheat straw into soil: Determination of gross $\mathrm{N}$ transformation rates by $15 \mathrm{~N}$-ammonium isotope dilution technique. Soil Biology and Biochemistry 37: 425-432. https://doi.org/10.1016/j.soilbio.2004.07.027

Talgre, L., Lauringson, E., Makke, A. \& Lauk, R. 2011. Biomass production and nutrient binding of catch crops. ŽemdirbysteAgriculture 98: 251-258. 
Talgre, L., Roostalu, H., Mäeorg, E. \& Lauringson, E. 2017. Nitrogen and carbon release during decomposition of roots and shoots of leguminous green manure crops. Agronomy Research 15: 594-601.

USDA 2011. East National Technology Support Center, 2011. Carbon to Nitrogen Ratios in Cropping Systems. Cited 10 May 2019. https://www.nrcs.usda.gov/Internet/FSE_DOCUMENTS/nrcseprd331820.pdf.

Watson, C.A., Topp, C.F.E., Reckling, M., Bergkvist, G., Bachinger, J., Preissel, S., Zander, P., Kuhlman, T., Lindström, K., Vanhatalo, A., Stoddard, F.L., Nemecek, T. \& Murphy-Bokern, D. 2017. Grain Legume Production and use in European Agricultural Systems. Advances in Agronomy 144: 235-303. https://doi.org/10.1016/bs.agron.2017.03.003

Appendix 1. Experiment design. Seven cropping systems (N1, N2, N3, N4, Org1, Org2 and Org3), 5-crop rotation, four replications, 140 plots.

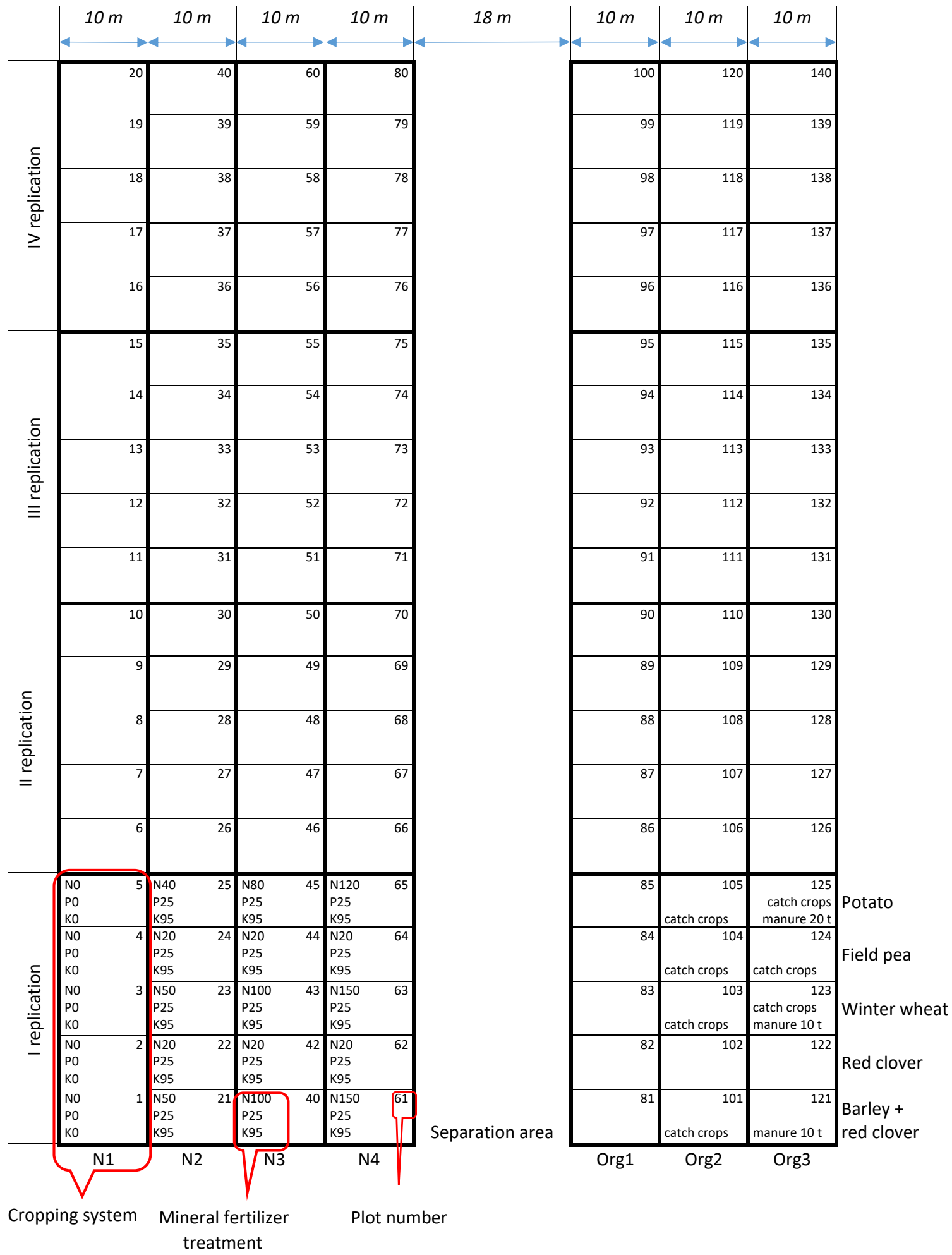


5-crop rotations (CR1-CR5) on adjacent field in 2012-2016 (one replication) and fertilisers NPK amounts applied in seven conventional and organic cropping systems

\begin{tabular}{|c|c|c|c|c|c|c|c|c|c|}
\hline \multirow[t]{2}{*}{ Year } & \multirow[t]{2}{*}{ Field/CR } & \multirow[t]{2}{*}{ Crop } & \multicolumn{4}{|c|}{ Mineral NPK applied $\left(\mathrm{kg} \mathrm{ha}^{-1}\right)$ to conventional cropping systems } & \multicolumn{3}{|c|}{$\begin{array}{l}\text { Catch crops (CC) and cattle manure (CM) applied to organic cropping } \\
\text { systems }\end{array}$} \\
\hline & & & N1 & N2 & N3 & N4 & Org1 & Org2 & Org3 \\
\hline \multirow[t]{5}{*}{2012} & $1 / \mathrm{CR} 1$ & Potato & 0 & N50P25K95 & N100P25K95 & N150P25K95 & 0 & CC & $\mathrm{CC}+\mathrm{CM} 20 \mathrm{Mg} \mathrm{ha}^{-1}$ \\
\hline & $2 / C R 2$ & Field pea & 0 & N2OP25K95 & N20P25K95 & N20P25K95 & 0 & CC & $\mathrm{CC}$ \\
\hline & $3 / \mathrm{CR} 3$ & Winter wheat & 0 & N50P25K95 & N100P25K95 & N150P25K95 & 0 & CC & $\mathrm{CC}+10 \mathrm{Mg} \mathrm{ha}^{-1}$ \\
\hline & $4 / C R 4$ & Red clover & 0 & 0 & 0 & 0 & 0 & 0 & 0 \\
\hline & $5 / C R 5$ & Barley + red clover & 0 & N40P25K95 & N80P25K95 & N120P25K95 & 0 & & CM 10 t ha $^{-1}$ \\
\hline \multirow[t]{5}{*}{2013} & $1 / \mathrm{CR} 1$ & Barley + red clover & 0 & N40P25K95 & N80P25K95 & N120P25K95 & 0 & & CM 10 t ha $^{-1}$ \\
\hline & $2 / C R 2$ & Potato & 0 & N50P25K95 & N100P25K95 & N150P25K95 & 0 & CC & $\mathrm{CC}+\mathrm{CM} 20 \mathrm{Mg} \mathrm{ha}^{-1}$ \\
\hline & $3 / \mathrm{CR} 3$ & Field pea & 0 & N20P25K95 & N20P25K95 & N20P25K95 & 0 & CC & CC \\
\hline & $4 / \mathrm{CR} 4$ & Winter wheat & 0 & N50P25K95 & N100P25K95 & N150P25K95 & 0 & CC & $\mathrm{CC}+\mathrm{CM} 10 \mathrm{Mg} \mathrm{ha}^{-1}$ \\
\hline & $5 / C R 5$ & Red clover & 0 & 0 & 0 & 0 & 0 & 0 & 0 \\
\hline \multirow[t]{4}{*}{2014} & $1 / \mathrm{CR} 1$ & Red clover & 0 & 0 & 0 & 0 & 0 & 0 & 0 \\
\hline & $2 / \mathrm{CR} 2$ & Barley + red clover & 0 & N40P25K95 & N80P25K95 & N120P25K95 & 0 & & CM $10 \mathrm{t} \mathrm{ha}^{-1}$ \\
\hline & $4 / C R 4$ & Field pea & 0 & N20P25K95 & N20P25K95 & N20P25K95 & 0 & CC & CC \\
\hline & $5 / C R 5$ & Winter wheat & 0 & N50P25K95 & N100P25K95 & N150P25K95 & 0 & CC & $\mathrm{CC}+\mathrm{CM} 10 \mathrm{Mg} \mathrm{ha}^{-1}$ \\
\hline \multirow[t]{5}{*}{2015} & $1 / \mathrm{CR} 1$ & Winter wheat & 0 & N50P25K95 & N100P25K95 & N150P25K95 & 0 & CC & $\mathrm{CC}+\mathrm{CM} 10 \mathrm{Mg} \mathrm{ha}^{-1}$ \\
\hline & $2 / C R 2$ & Red clover & 0 & 0 & 0 & 0 & 0 & 0 & 0 \\
\hline & $3 / \mathrm{CR} 3$ & Barley + red clover & 0 & N40P25K95 & N80P25K95 & N120P25K95 & 0 & & CM 10 t ha $^{-1}$ \\
\hline & $4 / \mathrm{CR} 4$ & Potato & 0 & N50P25K95 & N100P25K95 & N150P25K95 & 0 & CC & $\mathrm{CC}+\mathrm{CM} 20 \mathrm{Mg} \mathrm{ha}^{-1}$ \\
\hline & $5 / C R 5$ & Field pea & 0 & N20P25K95 & N20P25K95 & N20P25K95 & 0 & CC & CC \\
\hline \multirow[t]{5}{*}{2016} & $1 / \mathrm{CR} 1$ & Field pea & 0 & N20P25K95 & N20P25K95 & N20P25K95 & 0 & CC & CC \\
\hline & $2 / C R 2$ & Winter wheat & 0 & N50P25K95 & N100P25K95 & N150P25K95 & 0 & CC & $\mathrm{CC}+\mathrm{CM} 10 \mathrm{Mg} \mathrm{ha}^{-1}$ \\
\hline & $3 / \mathrm{CR} 3$ & Red clover & 0 & 0 & 0 & 0 & 0 & 0 & 0 \\
\hline & $4 / C R 4$ & Barley + red clover & 0 & N40P25K95 & N80P25K95 & N120P25K95 & 0 & & CM 10 t ha $^{-1}$ \\
\hline & $5 /$ CR5 & Potato & 0 & N50P25K95 & N100P25K95 & N150P25K95 & 0 & CC & $\mathrm{CC}+\mathrm{CM} 20 \mathrm{Mg} \mathrm{ha}^{-1}$ \\
\hline
\end{tabular}


AGRICULTURAL AND FOOD SCIENCE

I. Voor et al. (2020) 29: 494-504

Appendix 2. $\mathrm{N}$ content $\mathrm{kg} \mathrm{ha}^{-1}$ in soil in spring before and after growing field pea in different cropping systems and in different years

\begin{tabular}{|c|c|c|c|c|c|c|c|}
\hline & $\mathrm{N} 1$ & $\mathrm{~N} 2$ & N3 & N4 & Org1 & Org2 & Org3 \\
\hline 2012 before & $3141^{\mathrm{A}^{*} \mathrm{a}^{* *}}$ & $3750^{\mathrm{Ba}}$ & $3636^{\mathrm{Ba}}$ & $3661^{\text {Ba }}$ & $4050^{\mathrm{BCa}}$ & $4222^{\mathrm{Ca}}$ & $3685^{\mathrm{Ba}}$ \\
\hline 2013 after & $3187^{\mathrm{Aa}}$ & $3835^{\text {Ba }}$ & $3678^{\text {АВа }}$ & $3655^{\mathrm{ABa}}$ & $3727^{\mathrm{ABa}}$ & $3773^{\mathrm{ABa}}$ & $3870^{\text {Ba }}$ \\
\hline 2013 before & $3316^{\text {Aa }}$ & $3616^{\mathrm{ABa}}$ & $3678^{A B a}$ & $3769^{A B a}$ & $3922^{\mathrm{Ba}}$ & $3992^{\mathrm{Ba}}$ & $4147^{\mathrm{Ba}}$ \\
\hline 2014 after & $2664^{\mathrm{Aa}}$ & $2993^{A b}$ & $3185^{\mathrm{Aa}}$ & $3082^{A b}$ & $3123^{A b}$ & $3229^{\text {Aa }}$ & $3300^{\mathrm{Ab}}$ \\
\hline 2014 before & $2729^{\mathrm{Aa}}$ & $2645^{\mathrm{Aa}}$ & $2676^{\mathrm{Aa}}$ & $3007^{\text {Аa }}$ & $3000^{\mathrm{Aa}}$ & $2921^{\mathrm{Aa}}$ & $3073^{\mathrm{Aa}}$ \\
\hline 2015 after & $2737^{\mathrm{Aa}}$ & $2907^{\mathrm{Aa}}$ & $2697^{\mathrm{Aa}}$ & $2813^{\mathrm{Aa}}$ & $4432^{\mathrm{Bb}}$ & $4623^{\mathrm{Bb}}$ & $4420^{\mathrm{Bb}}$ \\
\hline 2015 before & $2903^{\mathrm{Aa}}$ & $2663^{\text {Аa }}$ & $2983^{\mathrm{Aa}}$ & $3115^{\text {Aa }}$ & $4507^{\text {Ba }}$ & $4940^{\text {Ba }}$ & $4721^{\mathrm{Ba}}$ \\
\hline 2016 after & $2962^{\text {Aa }}$ & $2988^{A b}$ & $2908^{\text {Aa }}$ & $2952^{\mathrm{Aa}}$ & $3259^{A b}$ & $3614^{\mathrm{Bb}}$ & $3666^{\mathrm{Bb}}$ \\
\hline 2016 before & $2846^{\text {Aa }}$ & $2945^{\mathrm{ABa}}$ & $3071^{\mathrm{ABCDa}}$ & $2983^{\mathrm{ABCa}}$ & $3389^{\mathrm{BCDa}}$ & $3521^{\mathrm{Da}}$ & $3463^{\mathrm{CDa}}$ \\
\hline 2017 after & $2628^{\mathrm{Aa}}$ & $3006^{\mathrm{ABCa}}$ & $3069^{\mathrm{ABCa}}$ & $2719^{\mathrm{ABa}}$ & $3325^{\mathrm{BCa}}$ & $3525^{c a}$ & $3487^{\mathrm{ca}}$ \\
\hline Average before & $2987^{\text {Aa }}$ & $3124^{\mathrm{Aa}}$ & $3209^{\text {Aa }}$ & $3307^{\text {Aa }}$ & $3774^{\text {Ba }}$ & $3919^{\text {ва }}$ & $3818^{\mathrm{Ba}}$ \\
\hline Average after & $2836^{\mathrm{Aa}}$ & $3146^{\mathrm{Aa}}$ & $3107^{\mathrm{Aa}}$ & $3044^{\mathrm{Aa}}$ & $3573^{\mathrm{Ba}}$ & $3753^{\mathrm{Ba}}$ & $3749^{\mathrm{Ba}}$ \\
\hline
\end{tabular}

